喉頭癌; 病理組織像からみた悪性度

一文献的考察一

和田好 純

\title{
Laryngeal Carcinoma; A Histopathological Evaluation of the Grade of Malignancy
}

\author{
-A Review of literature- \\ Yoshizumi Wada \\ (The University of Tokushima)
}

The TNM classification and histopathological diagnosis are important in making a prognosis for laryngeal carcinoma. However, there has been some difference in prognosis among cases in the same stage of the same histological diagnosis. Immunostaining of an antibody against the antigen present in the proliferating cycle of the tumor is a recently developed method for evaluating the tumor's proliferation acrivity. Evaluating the proliferation acrivity may be useful in deciding therapeutic policy, as well as in assuming prognosis, because it provides information which cannot be obtained by $\mathrm{H}$ and $\mathrm{E}$ staining. Of the proliferating cell antigens, proliferating cell nucler antigen (PCNA) is expected to be used clinically, because its antigenicity is said to be stable even after formalin fixation and paraffin embedding of the specimens. In this study, histopathological findings as a prognostic indicator for laryngeal carcinoma, and PCNA as an indicator of proliferation activity, are discussed with reference to literature.

Key words: laryngeal carcinoma, histopathological diagnosis, proliferating acrivity, PCNA

\section{はじめに}

癌は過剩な細胞増殖と定義1)されている。喉 頭癌に扔いて治療方針, 予後推定には, 腫瘍の 進展度により規定される TNM 分類, 病理組織 診断が重要な因子である。一般に組織学的予後 因子は組織型, 分化度, 增殖能を反映する因子, 進行度を反映する因子2) に分類される. 喉頭癌 に执いてほとんどは扁平上皮癌3)であるが，同 じ組織型でありながら同一 stage の症例間にも
予後の差があり，他の因子による悪性度診断が 必要と思われる. 分裂細胞数の多少 (mitotic index) は, 従来より増殖能の指標とされている が観察者による相違などの問題 ${ }^{4)}$ が指摘されて おり，再現性が高いとはい学ない。近年, 細胞 の増殖サイクルに連動して発現される抗原に対 する抗体を使った免疫染色により，腫瘍の増殖 能を推定することが行われるようになってきた. 増殖能を推定することは従来の $\mathrm{H}-\mathrm{E}$ 染色から 
得られない情報を補完するため, 治療方針, 予 後推定, あるいは治療効果判定に有用な補助診 断となる可能性が示唆され, 個々の喉頭癌の病 態を理解する上で不可欠な課題と考学られる.

増殖細胞抗原のなかで proliferating cell nuclear antigen (PCNA) はホルマリン固定, パ ラフィン包埋切片においても抗原性が安定して いるといわれ臨床応用が期待される. 本論文で は喉頭癌の予後因子としての病理組織診断およ び増殖細胞抗原としての PCNA につき文献的 に考察した。

\section{予後因子としての喉頭癌の 病理組織学的診断}

1. 分化度からみた悪性度

現在, 扁平上皮癌の悪性度は高分化型 ( 1 度), 中分化型（2 度），低分化型（3 度）に分類さ れている5)。喉頭癌に拈いて 1 度が $30 \% ， 2$ 度 が50\%，3 度が $20 \%$ である6).未分化細胞の割 合にて組織学的に悪性度を 4 度に分類した Broders 分類に対し岩本 ${ }^{7}$ は Broders の分類は 目測に頼るものと批判し発育先端部の組織像を 観察することを報告し, 角化の程度, 細胞間橋, 核分裂の多少, 細胞核の多形性により分化度を 4 度に分類し, 未分化なものほど再発率が高く, リンパ節転移が多く, 粘膜下進展が大きいと報

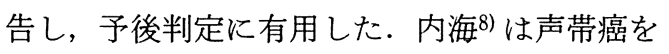
8 型に分類し, 細胞異型による組織学的悪性度 判定をし, 初期型の悪性度は低いものの, 晚期 型になるにつれて悪性度は高くなったと報告し ている. 分化度と予後につき批判的な意見9) 女 あるが, 分化度, 角化度, 構造異型, 細胞異型 などを参考に well-differentiated (grade 1), moderately-differentiated (grade 2), poorlydifferentiated (grade 3) に分類され, 一般に未 分化なものほど発育が早く, リンパ節転移が多 くなり予後は悪くなるといわれている3).

\section{2. 発育型からみた悪性度}

組織学的構築像による悪性度判定には腫瘍の 発育型を extensive type, expensive type, budding type に分けた今井の分類がある. exten- sive type とは, 癌実質が適当な幅をもって発 育するもので声帯癌の $85 \%$ がこの型とされる. expensive type とは, 延伸型に比べ著しい厚み を増した害質が肥大し拡張発育するもので, 声 門上癌の $75 \%$ がこの型とされる. budding type とは, 癌胞巣の厚さが薄く細胞が浸透するよら に発育する型で, 声門上癌の $10 \%$ にられ, そ の予後はよくない3). 岩本 ${ }^{10)}$ は240例の喉頭癌 について検討し, 細胞学的構築像による予後判 定は組織学的悪性度による判定よりも有用と報 告した。また，三吉11) は組織学的悪性度と発 育型について検討し, 組織学的悪性度による予 後判定は有用でなく, むしろ全体的組織学的構 築像つまり発育型が予後判定に有用としている.

3 . 間質反応からみた悪性度

石井 ${ }^{12)}$ は腫瘍の間質に注目し, 喉頭癌150例 につき腫瘍実質の示す態度と間質反応につき検 討を行った. 間質反応を結合織の増殖, 細胞浸 潤, 血管反応に分類し組織学的悪性度および腫 瘍発育型と比較検討した結果, 声門型, 声門下 型は増殖性反応が著明であり, 声門上型は浸出 性反応が著明であり，血管反応は声門上型にお いて著しいと述べている. 発育型と間質反応に は一定の傾向を示し budding type に拈いて浸 出反応が著明であり, 組織学的悪性度の高いも のでは血管反応が著明であったと述べ, 浸出性 反応，血管反応の著しいものに，予後不良のも のが多かったと報告している．前田 ${ }^{13)}$ は放射 線抵抗性喉頭癌について組織学的に間質反応を 検討し, 浸出反応, 血管反応は低下し増殖反応 は増大していたと述べ，放射線治療の適応を考 えるにあたって，間質の動態を参考にするべき だと報告している，浸出反応については，現在 のところ免疫応答反応と考えられ, 浸出反応が 強いほど臨床経過が良いとされる14). 1986年, Visser ${ }^{15)}$ は喉頭癌生検材料に対し, 基低膜の構 成成分である type 4 collagen と Laminin を酵 素抗体間接法にて染色した. その結果, type 4 collagen と Laminin の不整な断裂像を認め, 喉頭癌の微細浸潤の証明に有用とした。堤 ${ }^{16)}$ は 
声門上癌にし対し, type 4 collagen, Laminin の免疫組織学的検討を行い, 分化度と type 4 collagen の染色生が局所リンパ節の転移の有無 に対し重要度が高いと述べ, 浸潤性と type 4 collagenの染色性の間に有意な差を認めたと報 告している.

\section{増殖細胞抗原としての PCNA について}

1978年 miyachi ら ${ }^{17)}$ は全身性エリテマトー デス患者の約 $2 \%$ に増殖細胞の核とのみ反応す る自己抗体を見い出し，これに対応する抗原に 対し PCNA と命名し，この抗体は増殖細胞の 同定に有用となることを示唆した. 一方 Bravo ら ${ }^{18)}$ は増殖細胞に特異的にみられる分子量 $36 \mathrm{KD}$ の酸性蛋白質を二次元電気泳動解析に よって発見し cyclin と命名した. Tan ら ${ }^{19)}$ はポ リメラーゼ delta の活性を著しく高める補助蛋 白因子の分離に成功した. 1984年, Mathews ${ }^{20)}$ によって PCNA は G1 期細胞が S 期にはいる 直前にかならず核内に出現する細胞周期依存性 非ヒストン核内蛋白 cyclin と同一物質である

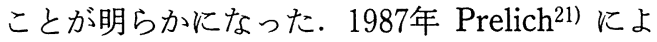
って PCNA は DNA ポリメラーゼ delta の補助 蛋白であることが判明した.この蛋白は二量体 として DNA ポリメラーゼ delta と結合18) して, 核へ移行して DNA 複製フォークの leading 鎖 の合成を行うと考えられている22).

蛍光抗体法で PCNA の観察はエタノールに 固定した細胞では細胞周期の $\mathrm{G} 1$ 後期より $\mathrm{S}$ 期 の核にのみ存在し，その核内分布は特異なパ ターンを示す23)。ホルムアルデヒドによる固定 では増殖期にある多くの細胞核に PCNA が局 在している24).

Robbins ら 25)は1987年ホルマリン固定，パラ フィン切片のヒト腫瘍組織に増殖マーカーとし て PCNA の免疫染色を行い, 組織学的悪性度 や分裂細胞数に応じた PCNA 陽性細胞数を観 察したと報告した。 Garcia ら ${ }^{26)}$ はアルコール 系固定, パラフィン切片にて PCNA 陽性細胞 を確認し，陽性細胞数とフローサイトメトリー によって得られた増殖分画がほぼ一致すると報
告している. ホルマリン固定, パラフィン切片 で免疫染色が可能であることにより各領域の腫 瘍に対し PCNA 陽性数を増殖能の指標とする 報告がなされている. Tabuchi ら27)はグリオー マ生検材料に対し PCNA 陽性細胞数と bromodeoxyuridine (BrdU) による標識率につき検討 し両者間の標識率はほぼ一致する結果を得, 組 織学的悪性度に一致したと報告している。 Takahashi ら 28) は悪性黒色腫に対し PCNA 陽 性細胞数を検討した結果, 組織学的悪性度, 臨 床的悪性度と一致した結果となり，増殖マー カーならびに予後推定に有用と報告している. Matsuno $5^{29)}$ は肝癌の結節内結節病変につき PCNA 陽性細胞数を検討した結果，高分化を 示す辺縁部には陽性細胞が少なく，中心部のは っきりした癌領域に陽性細胞を多く認めたとし， 増殖マーカーとして悪性度判断とした．胃癌に

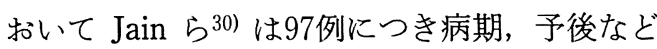
と PCNA 陽性細胞数につき検討し陽性細胞数 が多いほど予後は悪かったと報告している.

しかし，PCNA 陽性細胞を免疫染色にて同 定し症例間で比較するには，染色性の影響を考 虑すべきであり, 固定条件を一定にする必要が あり31) 今後の課題と思われる.

\section{まとめ}

喉頭癌の病理組織学的悪性度診断および今後 検討されるべき増殖能 (PCNA) につき文献的考 察を行った. 固定条件を一定にすれば免疫染色 にて PCNA 陽性細胞を同定し, 増殖能という 生物学的悪性度を客観的に評価することは可能 となり, 悪性度判定, 予後の推定に有用な補助 診断になる可能性が示唆される.

\section{参考文献}

1）武田勝男：腫瘍. 新病理学総論 2 版. $401 \sim 461$ 頁, 南山堂, 東京, 1981 .

2) 向井 清: 組織学的悪性度診断. 病理と臨床 $9: 844 \sim 847,1991$.

3）佐藤武男：喉頭癌の病理組織学. 喉頭癌 その 基礎之臨床 2 版. 89 144頁, 金原出版, 東 京, 1986. 
4) Baak JPA : Mitosis counting in tumors. Hum Pathol 21 : 683 685, 1991.

5) 日本頭頸部腫瘍学会: 病理組織分類. 臨床, 病 理, 頭頸部癌取扱い規約. 15 54頁, 金原出版, 東京, 1991 .

6）佐藤武男：喉頭癌. 耳喉 $50: 331 \sim 342,1978$.

7) 岩本彦之丞：喉頭癌における喉頭全摘後の再発 と癌組織像との関係. 耳喉 $23: 179 \sim 182,1951$.

8）内海重光: 声帯癌の進展型式とその臨床病理組 織学的研究. 日耳鼻 $73: 1488 \sim 1505,1970$.

9）中島重隆: 大切片標本による喉頭癌の病理組織 学的研究. 日耳鼻 $69: 54 \sim 75,1966$.

10）岩本彦之丞：喉頭癌の悪性度. 耳喉 $30: 316 \sim$ 319, 1958.

11）三吉康郎：㑨頭癌の臨床的ならびに病理組織学 的研究. 耳鼻臨床 $48: 404 \sim 412,1955$.

12) 石井 学: 喉頭癌の臨床的並びに病理組織学的 研究. 日耳鼻 $69: 833 \sim 861,1966$.

13）前田和雄: 放射線抵抗性喉頭癌の臨床病理組織 学的研究. 日耳鼻 $82: 141 \sim 156,1979$.

14）大竹英夫：頭頸部扁平上皮癌症例に批ける間質 反応の臨床的意義. 日耳鼻 $88: 1178 \sim 1192$, 1985.

15) Visser $R:$ Immunocytochemical detection of basement membrane antigens in the histopathological evaluation of laryngeal dysplasia and neoplasia. Histopathology $10: 171 \sim 180$, 1986.

16）堤康一郎：生検組織形態からみた声門上癌の臨 床病理学的研究. 日耳鼻 $91: 570 \sim 579,1988$.

17) Miyachi K, Fritzler MJ and Tan EM : Autoantibody to a nucler antigen in proliferating cells. J Immunol 121 : 2228 2234, 1987.

18) Bravo R, Fey SJ, Bellantin J, et al : Identification of a nucler and of a cytoplasmic polypeptide whose relative proportion are sensitive to changes in the rate of cell proliferation. Exp Cell Res $136: 311 \sim 319,1981$.

19) Tan CK, Castillo $C$, So AG, et al : An auxiliary protein for DNA polymerase delta from fetal calf thymus. J Biol Chem $261: 12310 \sim 12316$, 1986.

20) Mathews MB, Berstein RM, Franza BR, et al : Identity of the proliferating cell nucler antigen and cyclin. Nature $309: 374 \sim 376,1984$.

21) Prelich G : Functional identity of proliferating cell nucler antigen and a DNA polymerase delta auxiliary protein. Nature $326: 517 \sim 520$, 1987.

22) Prelich G and Stillman B : Cordinated leading and lagging strand synthesis during SV40 DNA replication in vitro requires PCNA. Cell 53 : 117 126, 1988.

23) Takasaki Y, Deng JS and Tan EM : A nucler antigen associated with cell proliferation and blast transformation; its distribution in synchromized cells. J Exp Med 154 : 1899 1909, 1981.

24）堤 寛: 免疫グロブリン, 3 自己抗体 $\mathrm{b}$ 各種 自己抗体を応用した疾患の検討. 病理と臨床 $4: 295 \sim 301,1986$.

25) Robbins BA, de la Vega D, Ogata K, et al : Immunohistochemical detection of proliferating cell nuclear antigen in solid human malignancies. Arch Pathol Lab Med 111: 841 845, 1987.

26) Garcia RL, Coltrera MD and Gown AM : Analysis of proliferative grade using antiPCNA/cyclin monoclonal antibodies in fixed, embedded tissues. Am J Pathol 4 : 733 739, 1989.

27) Tabuchi K, Honda $C$ and Nakane PK: Demonstration of proliferating cell nuclear antigen (PCNA/cyclin) in Glioma cells. Neurol Med Chir. 27 : 1 5, 1987.

28) Takahashi H, Strutton GM and Parsons PG : Determination of proliferating fractions in malignant melanomas by anti-PCNA/cyclin monoclonal antibody. Histopathol $18: 221 \sim$ 227, 1991.

29) Matsuno $Y$, Hirohashi S, Furuya $M$, et al : Heterogeneity of proliferative activity in nodule-in-nodule lesions of smoll hepatocellular carcinoma. J Cancer Res 81 : 1137 1140, 1990.

30) Jain S, Filipe MI, Hall PA, et al : Prognostic value of proliferating cell nuclear antigen in gastric carcinoma. J Clin Pathol 44 : 655 659, 1991. 
31）松野吉宏, 向井 清 : 増殖細胞核抗原 (PCNA).

病理と臨床 9 ：879～883, 1991.

(別刷請求先: 和田好純

( 770 徳島市蔵本町2-50-1

徳島大学医学部耳鼻咽喉科学教室) 